\title{
DNA sequencing and genotyping profile of the microsatellites of Y-STRs of the Beer-Alsabaa bedouins of Jordan as part of the Arabian genome project since 1995
}

\begin{abstract}
An account has been given to determine the DNA sequencing and genotyping profile of the microsatellites of Y-STRs of the Beer-Alsabaa Bedouins of Jordan as part of the continuous project of Arabian genome since 1995. The Alleles frequencies range from (3.3-100\%), whilst the genetic diversity ranges from (0-0.93). The Model of heliotype for the BeerAlsabaa Bedouins of Jordan was constructed and thus their exclusive DNA markers were the loci DYS437 and DYS 438 for allele's values of 14 and 15 respectively, both reaching frequency of $100 \%$. The DNA haplogroup of the Beer-Alsabaa Bedouins is (J1) which confirms that their belongings to the Qahtanite-lineage for their Y-chromosome genealogical landscape and thus match the tribal genealogical memory. The Phylogenetic-tree of BeerAlsabaa Bedouin shows that they have very close divergence to both Palestinians and Yamani as they appeared in the same cluster. Moreover, the Fst between Beer-Alsabaa Bedouin and other Arabian populations ranged between $(0.0242-0.0376)$ and thus shows the low genetic diversity and thus the high profile of genealogical relatedness. The results have been registered and deposited in the International DNA Gene Bank of Y-Chromosome Haplotype Reference Database (YHRD) under the Accession Numbers YA003522 and YA003523.
\end{abstract}

Keywords: arabian genealogy, arab qahtanite and adnanite, genetic distance
Volume 3 Issue 3 - 2018

\section{Ihsan Ali Almahasneh,' Berjas Abumsimir, ${ }^{2}$ Moulay Mustapha Ennaji'}

'Department of Biotechnology, University of Sharjah, UAE

${ }^{2}$ Faculty of Sciences and Techniques Mohammedia, Hassan II University of Casablanca, Morocco

Correspondence: Ihsan Ali Almahasneh, Department of Biotechnology, Faculty of Science, University of Sharjah, POBOX 27272, Sharjah, UAE, Previously: University of Al al-Bayt, Jordan, Email imahasneh@sharjah.ac.ae

Received: May 29, 2018| Published: June 13, 2018

\section{Introduction}

In humans, the $\mathrm{Y}$ chromosome spans 58 million base pairs and represents approximately $0.38 \%$ of the total DNA in a human cell. The human Y chromosome contains 86 genes, ${ }^{1}$ many of the genes on Y-chromosome are involved in male sexual determination and development. ${ }^{2}$ The bulk of the $\mathrm{Y}$ chromosome which does not recombine is called the non-recombining region of the $\mathrm{Y}$ chromosome (NRY), which is composed of the DNA segments known as Short Tandem Repeats (STRs). The STRs polymorphism are categorized by length of the repeated units such as Di nucleotide (CA), Trinucleotide (TAT), Tetra nucleotide (TTTA), Pentanucleotide (TAAAA), Hexa nucleotide (AGAGAT), ${ }^{3,4}$ (Figure 1). As Y-chromosome is paternally inherited as haploid Y-DNA segment and passed down from father to son unchanged from generation to another except by the gradual accumulation of mutations, the STRs of the Y chromosome have proved to be a very powerful tool in tracing movements of males in human population history. ${ }^{5}$ The applications of Y-STRs are becoming increasingly important because of their male specificity and the informativeness of the haplotypes they define and also provide useful discriminating power in individual identification and the geographical differentiation of Y haplotypes of the male genetic map. ${ }^{6}$

Recently, there has been a worldwide growing interest on the genotyping profile of Y-STRs among different nations, populations and some ethnic groups around the world..$^{7-10}$ In comparison with other parts of the world, there is a lack of information on the Arabian genealogy as well as their tribal migration and dispersal around the world. ${ }^{11-13}$ Currently, many attempts are being made by the National Geographic Society and the private companies Family Tree DNA (https://www.familytreedna.com) to resolve the genealogical genotyping of Arabian tribes and lineages. Among other Bedouins of Jordan (Southern, Middle and Northern), the Beer-Alsabaa Bedouins of Jordan are recognized by the Jordanian constitution and Laws of Bedouins and that they are composed of four major clans (Alazazma, Al-Tayaha, Al-Tarabin, and Aljbarat) living mainly among the Middle Bedouins. Beer-Alsabaa Bedouins represent one of most conservative populations in the Arabian region, and has an exceptional genetic importance due to their genealogical culture and lifestyle driving force for the consanguineous marriage as favored and respected in all their communities reaching up to $60 \%$ as they lives in the isolated and rural communities. The aim of the present research, therefore, is to determine the DNA genotyping profile of the microsatellites of Y-STRs of the Beer-Alsabaa Bedouins of Jordan as part of the Arabian genome project.

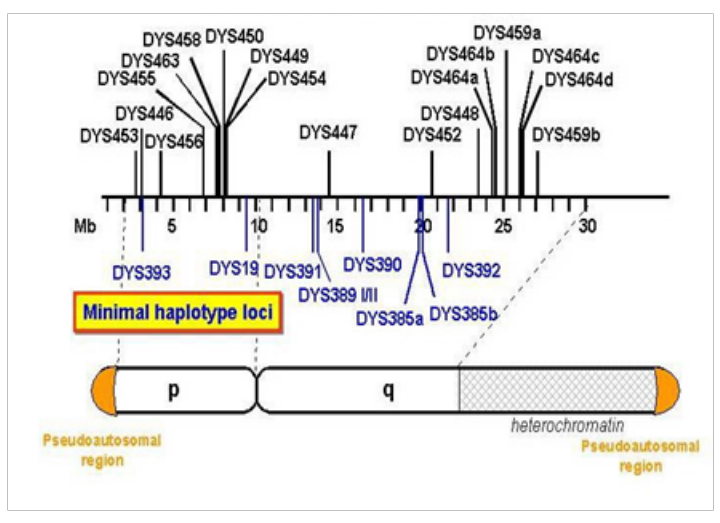

Figure I Y-STR positions along Y chromosome. ${ }^{4}$ 


\section{Materials and methods}

\section{Sequencing and genotyping of the DNA Y-STRs}

DNA isolation, amplification and allies sequencing and sizing was conducted according the manufacture protocols; using the wizard genomic DNA isolation-kit ${ }^{\circledR}$ (Promega, USA), Amp FlSTR ${ }^{\circledR}$ Yfiler $^{\mathrm{TM}}$ PCR Amplification Kit on the Gene-Amp-PCR System 9700 Thermo Cycler (Applied Bio system) and the ABI Prism ${ }^{\circledR 3} 310$ Genetic Analyzer (Applied Bio systems) as equipped with the Gene Scan-500 Internal Lane Size Standard (LIZ-500), Data Collection Software Version 3.1 and Gene Mapper ID Software Version 4 from Applied Bio systems to determine the allelic repeats by applying $\mathrm{Y}$ Filer Allelic Ladder. The genealogical Haplogroup of each haplotype was determined using the Athey's Haplogroups Predictor version 3.16 .

\section{Statistical analysis}

Allelic frequencies were estimated by direct counting and the gene diversity was calculated using in-house-built program. Using the public demine of the YHRD (www.yhrd.org), AMOVA test was used to determine the Pair wise values of $\Phi$ st, an analogue of Fst, MDS plot as compared to the (6) Arabian populations. A dendrogram of clusters analysis was calculated using Dendroscope software, version 3.5.7). ${ }^{14}$ Phylogeny analysis was created by online Trex statistical tool: http:// www.trex.uqam.ca

\section{Quality assurance}

We have participated in the Quality Assurance Test as stipulated by the YHRD and therefore our results have been registered and deposited in the International Y-Chromosome Haplotype Reference
Database (YHRD), under the Accession Numbers YA003522 and YA003523 (www.yhrd.org). Furthermore, the data were then stored in our local Mahasneh Arabian Y-linage Database (MAYD).

\section{Results and discussion}

The Alleles frequencies ranges from $(3.3-100 \%)$, whilst the genetic diversity ranges from (0-0.93) (Table 1). The Model of haplotype for the Beer-Alsabaa Bedouins of Jordan was constructed and thus their exclusive DNA markers were the loci DYS437 and DYS 438 for allele's values of 14 and 15 respectively, both reaching frequency of $100 \%$ (Table 1). The Fst of AMOVA test between Beer-Alsabaa Bedouin from other Arabian populations were with Palestinians (0.0242), Yemeni (0.0262), Moroccan (0.0268), Libyan (0.0272), Tunisians (0.0376) respectively, with significant P-values $(\mathrm{P}<0.05)$ with all subjects: $0.00,0.0007,0.0008,0.0008$ and 0.0022 respectively (Table 2), which shows the low level of diversity and thus the high close relatedness with the DNA of the Palestinians and Yamani. The Phylogenetic divergence of Beer-Alsabaa Bedouins with other Arabian populations revealed that their closes lineages are Palestinians and Yamani as they appeared in the same cluster whilst the North African Arabs showed the second cluster (Figure 2). The DNA haplogroup of the Beer-Alsabaa Bedouins was (J1) which confirms that they do belong to the Qahtani-lineage for their Y-chromosome genealogical landscape and thus match the tribal genealogical memory. In contrast with the $2^{\text {nd }}$. Cluster for North African Arabs, they are have a different sub-divergence of genealogy as they belongs mainly to the E1b1 (African) haplogroup and also the Adnanite (J2) haplogroup of the migrated (from Arabian peninsula towards North Africa) tribes during the $7^{\text {th }}$ century Banu Helal, Banu Maaqel and Banu Sulaym.

Table I Alleles Frequency and Diversity for I7-YSTRs Markers of Beer-Alsabaa Bedouin Population

\begin{tabular}{|c|c|c|c|c|c|c|c|c|c|c|c|c|c|c|c|c|c|}
\hline $\begin{array}{l}\text { Alleles } \\
\text { sequence } \\
\text { value }\end{array}$ & $\begin{array}{l}\text { DYS } \\
456\end{array}$ & $\begin{array}{l}\text { DYS } \\
389 i\end{array}$ & $\begin{array}{l}\text { DYS } \\
390\end{array}$ & $\begin{array}{l}\text { DYS } \\
389 \mathrm{ii}\end{array}$ & $\begin{array}{l}\text { DYS } \\
458\end{array}$ & $\begin{array}{l}\text { DYS } \\
19\end{array}$ & $\begin{array}{l}\text { DYS } \\
385 a\end{array}$ & $\begin{array}{l}\text { DYS } \\
385 b\end{array}$ & $\begin{array}{l}\text { DYS } \\
393\end{array}$ & $\begin{array}{l}\text { DYS } \\
391\end{array}$ & $\begin{array}{l}\text { DYS } \\
439\end{array}$ & $\begin{array}{l}\text { DYS } \\
635\end{array}$ & $\begin{array}{l}\text { DYS } \\
392\end{array}$ & $\begin{array}{l}\text { DYS } \\
\text { H4 }\end{array}$ & $\begin{array}{l}\text { DYS } \\
437\end{array}$ & $\begin{array}{l}\text { DYS } \\
438\end{array}$ & $\begin{array}{l}\text { DYS } \\
448\end{array}$ \\
\hline 9 & & & & & & & 13.3 & & & & & & & & & & \\
\hline 10 & & & & & & & & & & 56.6 & & & & & & & \\
\hline II & & & & & & & & & & 40 & 60 & & 33.3 & 96.6 & & 100 & \\
\hline 12 & & 6.6 & & & & & & & 43.3 & & 33.3 & & 3.3 & 3.3 & & & \\
\hline 13 & & 83 & & & & 3.3 & 50 & & 65.6 & & & & & & & & \\
\hline 14 & 40 & 10 & & & & 86.6 & 3.3 & & & & & & 50 & & 100 & & \\
\hline 15 & 60 & & & & & & & & & & & & & & & & \\
\hline 16 & & & & & & & & & & & & & & & & & \\
\hline 17 & & & & & 3.3 & & & 10 & & & & & & & & & \\
\hline 18 & & & & & 6.6 & & & 30 & & & & & & & & & \\
\hline 19 & & & & & 53.3 & & & 6.6 & & & & & & & & & 16.6 \\
\hline 20 & & & & & 6.6 & & & & & & & & & & & & 83.3 \\
\hline 21 & & & & & & & & & & & & 100 & & & & & \\
\hline 22 & & & 3.3 & & & & & & & & & & & & & & \\
\hline 23 & & & 53.3 & & & & & & & & & & & & & & \\
\hline 24 & & & 33 & & & & & & & & & & & & & & \\
\hline 25 & & & 3.3 & & & & & & & & & & & & & & \\
\hline
\end{tabular}


Table Continued

\begin{tabular}{|c|c|c|c|c|c|c|c|c|c|c|c|c|c|c|c|c|c|}
\hline $\begin{array}{l}\text { Alleles } \\
\text { sequence } \\
\text { value }\end{array}$ & $\begin{array}{l}\text { DYS } \\
456\end{array}$ & $\begin{array}{l}\text { DYS } \\
389 i\end{array}$ & $\begin{array}{l}\text { DYS } \\
390\end{array}$ & $\begin{array}{l}\text { DYS } \\
389 \mathrm{ii}\end{array}$ & $\begin{array}{l}\text { DYS } \\
458\end{array}$ & $\begin{array}{l}\text { DYS } \\
19\end{array}$ & $\begin{array}{l}\text { DYS } \\
385 a\end{array}$ & $\begin{array}{l}\text { DYS } \\
385 b\end{array}$ & $\begin{array}{l}\text { DYS } \\
393\end{array}$ & $\begin{array}{l}\text { DYS } \\
391\end{array}$ & $\begin{array}{l}\text { DYS } \\
439\end{array}$ & $\begin{array}{l}\text { DYS } \\
635\end{array}$ & $\begin{array}{l}\text { DYS } \\
392\end{array}$ & $\begin{array}{l}\text { DYS } \\
\text { H4 }\end{array}$ & $\begin{array}{l}\text { DYS } \\
437\end{array}$ & $\begin{array}{l}\text { DYS } \\
438\end{array}$ & $\begin{array}{l}\text { DYS } \\
448\end{array}$ \\
\hline \multicolumn{18}{|l|}{26} \\
\hline \multicolumn{18}{|l|}{27} \\
\hline 28 & & & & 3.3 & & & & & & & & & & & & & \\
\hline 29 & & & & 6.6 & & & & & & & & & & & & & \\
\hline 30 & & & & 53.3 & & & & & & & & & & & & & \\
\hline 31 & & & & 6.6 & & & & & & & & & & & & & \\
\hline G.D. & & 0.31 & 0.63 & 0.73 & 0.63 & 0.26 & 0.76 & 0.93 & 0.51 & 0.54 & 0.55 & 0 & 0.66 & 0.68 & 0 & 0 & 0.29 \\
\hline Model ht. & 15 & 13 & 23 & 30 & 18 & 14 & 13 & 18 & 13 & 10 & II & 21 & 14 & II & 14 & 10 & 20 \\
\hline
\end{tabular}

GD, Genetic Diversity

Table 2 Pair wise Fst and P-values and Divergent signal Bloomberg $\mathrm{K}$ test parameters between Beer-Alsabaa Bedouins population and five neighboring populations

\begin{tabular}{lllllll}
\hline Population & BB & AP & BL & AR & ST & SY \\
\hline BB & - & 0 & 0.0007 & 0.0008 & 0.0022 & 0.0008 \\
AP & 0.0242 & - & 0 & 0 & 0 & 0 \\
BL & 0.0272 & 0.004 & - & 0 & 0 & 0 \\
AR & 0.0268 & 0.0039 & 0.0061 & - & 0.0002 & 0 \\
ST & 0.0376 & 0.0131 & 0.0162 & 0.0067 & - & 0 \\
SY & 0.0262 & 0.003 & 0.0061 & 0.0055 & 0.015 & - \\
& Divergent signal blomberg K test parameters & & & 0 \\
SD & 0.02223927 & 0.0104466 & 0.00310227 & 0.00218096 & 0.00040583 I & 0 \\
PV & 0.79880621 & 0.1762587 & 0.01554389 & 0.007682379 & 0.000266005 & 0 \\
CP & 0.79880621 & 0.9750649 & 0.99060876 & 0.998291138 & I & I
\end{tabular}

BB, beer-alsabaa bedouins; AP, arab palestinians; BL, benghazi libyan; AR, arab rabat; SY. Sana'a yemeni; SD, standard deviation; PV, proportion of variance; CP, cumulative proportion

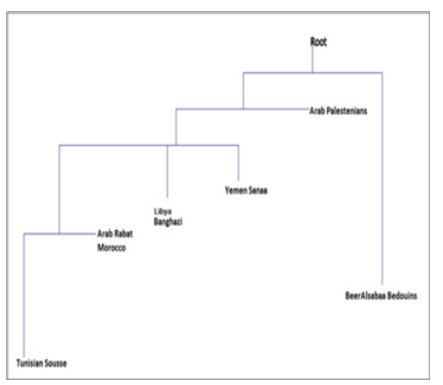

(A)



(B)

Figure 2 (A) Phylogenetic Interfere tree for the compared Arabian populations with Beer-Alsabaa Bedouin population (Trex statistical online tool: http://www.trex.uqam.ca). (B) Circular Dendrogram for hierarchical cluster analysis of 30 samples (22 haplotype) of Beer-Alsabaa Bedouin population (Dendroscope software, $\mathrm{V}$ 3.5.7).

\section{Conclusion}

For the first time, we present a conclusive evidence on the Y-STRs DNA Model of haplotype for the Beer-Alsabaa Bedouins of Jordan and specified their exclusive Y-STRs DNA markers where the loci DYS437 and DYS 438 for alleles values of 14 and 15 respectively,

both reaching frequency of $100 \%$. The DNA haplogroup of the BeerAlsabaa Bedouins is (J1) which confirms that their belongings to the Qahtanite-lineage for their Y-chromosome genealogical landscape and thus match the tribal genealogical memory. Moreover, the Fst between Beer-Alsabaa Bedouin and other Arabian populations ranged between (0.0242-0.0376) and thus shows the low genetic diversity and thus the high profile of genealogical relatedness. Our results are highly important in providing us with a better understanding of the genealogical genotyping profile to be correlated with the most common familial and genealogical-genetic diseases and the epidemiology among Arabian populations for better management towards establishment of gene therapy platform in the region.

\section{Acknowledgements}

We would like to thank University of AL al-Bayt, Jordan for providing facilities and the team of Medical Biotechnology Laboratory, Hassan II University of Casablanca, Morocco for their integral effort on bioinformatics analysis of the Data. Thanks are also due to the donors of the DNA.

\section{Conflict of interest}

The author declares there is no conflict of interest. 


\section{Refrences}

1. Pontes ML, Pena JA, Sanchez MAA, et al. Y chromosome STRs in the north of Portugal. International Congress Series. Elsevier. 2004;1261:350-352.

2. Brinkmann B, Klintschar M, Neuhuber F, et al. Mutation Rate in Human Microsatellites: Influence of the Structure and Length of the Tandem Repeat. Am J Hum Genet. 1998;62(6):1408-1415.

3. Butler JM, Hill CR, Decker AE, et al. New Autosomal and Y-Chromosome STR Loci: Characterization and Potential Uses, Biochemical Science Division. Proceedings of the 18th International Symposium on Human Identification, 2007 October 4; Fairfield: National Institute of Standards and Technology; 2007.

4. Hammer M, Redd AJ. Forensic Applications of Y chromosome STRs and SNPs. Forensic Science International. 2016. p. 97-111.

5. Mukherjee N, Nebel A, Oppenheim A, et al. High-resolution analysis of Y-chromosomal polymorphisms reveals signatures of population movements from Central Asia and West Asia into India. J Genet. 2001;80(3):125-135.

6. Parkin EJ, Kraayenbrink T, Opgenort JR, et al. Diversity of 26-locus Y-STR haplotypes in a Nepalese population sample: isolation and drift in the Himalayas, Forensic Sci Int. 2006;166(2):176-181.

7. Boattini A, Sarno S, Pedrini P, et al. Traces of medieval migrations in a socially stratified population from Northern Italy. Evidence from uniparental markers and deep-rooted pedigrees. Heredity. 2015;114(2):155-162.
8. Martínez Cruz B, Harmant C, Platt DE, et al. Evidence of pre-Roman tribal genetic structure in Basques from uniparentally inherited markers. Molecular Biol Evol. 2012;29(9):2211-2222.

9. Underhill PA, Myres NM, Rootsi S, et al. Separating the post-Glacial coancestry of European and Asian Y chromosomes within haplogroup R1a. Eur J Hum Genet. 2010;18(4):479-484.

10. Campbell KD. Geographic patterns of haplogroup R1b in the British Isles. Journal of Genetic Genealogy. 2007;3(1):1-13.

11. Mahasneh. Genetic profiling of the 5-top cancers among Arabian populations in relation to their genealogical landscape: Towards establishment of gene therapy platform in the region. Int $J \mathrm{Mol}$ Biol Open Access. 2018;3(2):54-56.

12. Elmrghni S, Coulson Thomas YM, Kaddura M, et al. Population genetic data for 17 Y STR markers from Benghazi (East Libya). Forensic Sci Int Genet. 2012;6(2):224-227.

13. Aboukhalid R, Bouabdellah M, Abbassi M, et al. Haplotype frequencies

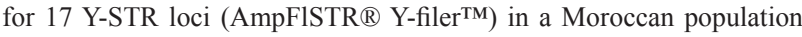
sample. Forensic Science International Genetics. 2010;4(3):73-74.

14. Huson DH, Scornavacca C. Dendroscope 3: an interactive tool for rooted phylogenetic trees and networks. Systematic Biology. 2012;61(6):10611067. 